\title{
Evaluation of the new ECOWAS directive on tobacco taxation
}

\section{Mohamed Ane ( $\nabla$ mohamed.ane@laposte.net) \\ Artois University}

\section{Research Article}

Keywords: tobacco, taxation, prevention, public health, ECOWAS, West Africa

Posted Date: May 17th, 2021

DOI: https://doi.org/10.21203/rs.3.rs-513473/v1

License: @ (1) This work is licensed under a Creative Commons Attribution 4.0 International License. Read Full License 


\section{Abstract}

This paper provides an assessment of the level of implementation of the new 2017 ECOWAS Directive on Tobacco Products Tariff and Tax Policy in Member States. This stricter directive recommends that member states apply a minimum excise duty of $50 \%$ of the pre-tax (exfactory) selling price of imported or domestic tobacco products in order to reduce the prevalence of tobacco use among the population. It is clear from this research that most Member States are still not complying with the recommended tax provisions. Some countries continue to apply an excise rate of less than $50 \%$, while others are satisfied with the necessary rate. While Ghana continues to have the highest excise rate $(175 \%)$ in the economic union, countries such as Togo, Benin, and Senegal have made relatively more efforts to increase the excise rate. Indeed, Togo tripled its rate, followed by Benin by two. Senegal, in addition to having increased its rate by one and a half, is the only country to have introduced a minimum collection price per package to avoid price drops. However, while efforts have been made in terms of restrictions on use, promotion and advertising, they are likely to be undermined by the low enforcement of tax rates. Thus, for a comprehensive tobacco control strategy, we suggest that efforts to increase tobacco taxation within ECOWAS be increased in proportion to inflation and changes in disposable income per capita, recognizing that low-income people are more sensitive to any price increase.

\section{Introduction}

Tobacco use is an epidemic that now kills more than 8 million people each year worldwide, the majority of whom are current or former smokers, and nearly 1.2 million non-smokers are involuntarily exposed to secondhand smoke [1]. In addition, more than $80 \%$ of the world's 1.3 billion smokers live in developing countries [1]. This will be a major public health challenge in Africa in the future, due to its projected doubling of population by 2050 [2]. While the African population is getting younger, the European population is getting older, with a median age of 45 years, the highest in the world [3]. This contrasting demographic structure may explain the decline in smoking observed in recent years in Europe, while smoking in Africa, although still low, is increasing rapidly [4].

To protect people and societies from the social harm and health consequences of tobacco use, its by-products and exposure to tobacco smoke, the World Health Organization (WHO) has identified several strategies, including increasing the price (inflation-adjusted price) of tobacco through taxation. It recommends increasing tobacco taxes to at least $70 \%$ of retail prices before taxes [5]. Unfortunately, this economic response seems to be underutilized by countries, especially in ECOWAS countries, as they apply a much lower minimum rate of $15 \%$ compared to $60 \%$ in the European Union countries.

However, following the recommendations of the $\mathrm{WHO}$ and aware of its role in preserving the health of populations and protecting them from the health and economic harms of tobacco use, ECOWAS decided in 2017 to propose to Member States a new, more binding directive whose main objective is to harmonize in the medium and long term the legislation on excise duties on tobacco products. Thus, during the seventyninth ordinary session of the Council of Ministers held in Abuja, capital of Nigeria, from December 13 to 14, 2017, ECOWAS clearly prescribed through Article 8 of Chapter 4 entitled Structure of excise duties and applicable rates of Directive C/DIR.1/12/17[1] on the harmonization of excise duties on tobacco products in the Member States that the floor rate applicable to the ad valorem duty must now be greater than or equal to $50 \%$ (compared to $15 \%$ with the previous directive) of the retail price without determining a ceiling rate. A specific tax of USD $0.02 /$ cigarette and USD 20/net kilogram for other tobacco products is associated with it. Member States had three years to adopt such a directive from January 1, 2018.

In practice, there are several taxation systems, including excise duties, which are indirect taxes levied on products such as tobacco. A distinction must be made between ad valorem taxes and specific taxes in the overall excise rate. The former is a tax on the price of the product sold; more expensive brands are therefore taxed more, which works to their disadvantage compared to cheaper brands. On the other hand, the specific tax is attached to a volume of sales and not to a price, for example a tax per 1000 cigarettes. Thus, a pack of cigarettes will be taxed for the same amount, regardless of its sales price. While mixed taxation is possible, the two taxes do not have the same objectives in terms of price, tax revenue and profit depending on the market structure. A compromise must therefore be found. The main issue is the adoption of an optimal tax regime. This question is difficult to address because it has been the subject of few or no empirical studies [6] for developing countries, which may justify the originality of our work.

Based on these lessons, this article takes stock of the implementation of the new ECOWAS directive in member states. The objective is to analyze the level of implementation of this directive through a literature review of existing texts related to tobacco taxation in each member state in order to (re)construct an updated database on tobacco taxation. In the first section, we describe the research methodology adopted for this work. In the second section, we show the specificities of the policies (legislation and taxation) of the ECOWAS countries. In the third section, we analyze the structure of excise duties in the economic space and finally in the last section, we evaluate the implementation of the new ECOWAS directive on excise duties.

[1] http://ecotipa.ecowas.int/wp-content/uploads/2018/05/3-DIRECTIVE-TOBACO-FRE-CM-1.pdf

Page 2/11 


\section{Research Methodology}

Regarding data collection on tobacco taxation texts, we focused our investigation on the scientific literature produced by the main actors involved in tobacco control. These include the World Health Organization (WHO), public authorities, civil society organizations (CSOs) and research centers. To do this, we first consulted the WHO Africa Region website, which provides extensive and up-to-date information on the WHO Framework Convention on Tobacco Control. Descriptive "country profile" type summary sheets are available to facilitate a vertical reading of public policies and to be able to cross-reference them for comparisons within countries. While the available data on tobacco taxation and prices allow us to understand their evolution, unfortunately they only concern the percentage of taxes (as well as the price) of the most consumed brand of 20 cigarettes[1], but they do not allow us to have a succinct idea of the application of the new ECOWAS directive.

Then, to fill this gap, the government websites (Ministry of Economy and Finance, public revenue offices, official journals, general tax codes, etc.) of each Member State were consulted for official texts, taking 2018 as the reference year. The purpose of this exercise is to ensure that the provisions of the new directive are included. The ECOWAS website has also been used to learn about the new directive through the laws and regulations section. Finally, the websites of research centers or CSOs provided a critical mass of information (scientific articles, research reports, etc.) with specific keywords: tobacco, taxation, smoking, ECOWAS, West Africa. In the non-French speaking ECOWAS countries (Cape Verde, Ghana, Gambia, Guinea Bissau, Liberia, Nigeria, Sierra Leone), finding documents related to their latest finance laws was the main difficulty encountered. Similarly, the "laws and regulations" section of the ECOWAS website provides little or no information on excise duties on tobacco products. Table 1 below provides the details of this literature review.

Table 1: Data collected 


\begin{tabular}{|c|c|c|c|}
\hline Theme & $\begin{array}{l}\text { Information } \\
\text { collected }\end{array}$ & Comments & \\
\hline \multicolumn{4}{|l|}{ Institutional websites } \\
\hline World Health Organization (WHO)/Africa Region & \multirow{2}{*}{$\begin{array}{l}\text { Tobacco } \\
\text { control }\end{array}$} & \multirow{2}{*}{$\begin{array}{l}\text { Recent reports on the } \\
\text { global tobacco epidemic }\end{array}$} & \multirow{2}{*}{$\begin{array}{l}\text { Country prevalence levels and } \\
\text { national tobacco control } \\
\text { policies }\end{array}$} \\
\hline https://www.afro.who.int/health-topics/tobacco-control & & & \\
\hline & \multirow[t]{2}{*}{$\begin{array}{l}\text { Tobacco } \\
\text { control }\end{array}$} & \multirow[t]{2}{*}{$\begin{array}{l}\text { National Tobacco Control } \\
\text { Profiles }\end{array}$} & \multirow[t]{2}{*}{$\begin{array}{l}\text { Price and taxes only for the } \\
\text { most consumed brand }\end{array}$} \\
\hline https://www.who.int/tobacco/global_report/en/ & & & \\
\hline & \multirow{2}{*}{$\begin{array}{l}\text { Tobacco } \\
\text { control }\end{array}$} & \multirow{2}{*}{$\begin{array}{l}\text { Excel files on taxes, prices } \\
\text { of tobacco products }\end{array}$} & \multirow{2}{*}{$\begin{array}{l}\text { Country comparisons: prices } \\
\text { and taxes }\end{array}$} \\
\hline https://www.tobaccocontrollaws.org/legislation/factsheet/ & & & \\
\hline \multirow{2}{*}{$\begin{array}{l}\text { Economic Community of West African States (ECOWAS) } \\
\text { https://www.ecowas.int/?lang=fr }\end{array}$} & \multirow[t]{2}{*}{$\begin{array}{l}\text { Laws and } \\
\text { regulations }\end{array}$} & $\begin{array}{l}\text { Common external tariff } \\
(\mathrm{CET}) \text {, excise duties }\end{array}$ & \multirow[t]{2}{*}{$\begin{array}{l}\text { Little information on tobacco } \\
\text { control policies }\end{array}$} \\
\hline & & $\begin{array}{l}\text { Financial laws of member } \\
\text { countries, ECOWAS } \\
\text { directives }\end{array}$ & \\
\hline \multirow{2}{*}{$\begin{array}{l}\text { West African Economic and Monetary Union (WAEMU) } \\
\text { http://www.uemoa.int/ }\end{array}$} & \multirow[t]{2}{*}{$\begin{array}{l}\text { Laws and } \\
\text { regulations }\end{array}$} & $\begin{array}{l}\text { Common external tariff } \\
(\mathrm{CET}) \text {, excise duties }\end{array}$ & \multirow[t]{2}{*}{$\begin{array}{l}\text { Little information on tobacco } \\
\text { control policies }\end{array}$} \\
\hline & & $\begin{array}{l}\text { Member countries' finance } \\
\text { laws, WAEMU directives }\end{array}$ & \\
\hline \multicolumn{4}{|l|}{ Research centers } \\
\hline $\begin{array}{l}\text { International Center for Tax and Development (ICTD) } \\
\text { https://www.ictd.ac/fr/accueil/ }\end{array}$ & $\begin{array}{l}\text { Tobacco } \\
\text { taxation }\end{array}$ & $\begin{array}{l}\text { Scientific articles on } \\
\text { tobacco taxation }\end{array}$ & $\begin{array}{l}\text { Useful for the study of DC } \\
\text { taxation }\end{array}$ \\
\hline $\begin{array}{l}\text { International Development Research Centre (IDRC) } \\
\text { https://www.idrc.ca/fr/search?query=tabac\&page=1 }\end{array}$ & Tobacco & $\begin{array}{l}\text { Scientific articles on } \\
\text { tobacco public policy }\end{array}$ & $\begin{array}{l}\text { Useful for studying tobacco } \\
\text { control policies in developing } \\
\text { countries }\end{array}$ \\
\hline $\begin{array}{l}\text { Consortium for Economic and Social Research (CESR) } \\
\text { http://www.cres-sn.org/ }\end{array}$ & $\begin{array}{l}\text { Tobacco } \\
\text { and } \\
\text { tobacco } \\
\text { related } \\
\text { projects }\end{array}$ & $\begin{array}{l}\text { Research reports, policy } \\
\text { briefs, scientific papers on } \\
\text { regional tobacco projects }\end{array}$ & $\begin{array}{l}\text { Useful for studying tobacco } \\
\text { control policies in the sub- } \\
\text { region }\end{array}$ \\
\hline \multicolumn{4}{|l|}{ Civil Society Organizations (CSO) Websites } \\
\hline $\begin{array}{l}\text { African Tobacco Control Alliance (ATCA) } \\
\text { https://atca-africa.org/en/about-us/what-is-atca }\end{array}$ & $\begin{array}{l}\text { Tobacco } \\
\text { control }\end{array}$ & $\begin{array}{l}\text { Cooperation between } \\
\text { CSOs and governments }\end{array}$ & $\begin{array}{l}\text { Useful to remind governments } \\
\text { of the tobacco guidelines and } \\
\text { WHO recommendations. }\end{array}$ \\
\hline $\begin{array}{l}\text { Tobacco Observatory in French-speaking Africa (OTAF) } \\
\text { https://www.otaf.info/node/160 }\end{array}$ & $\begin{array}{l}\text { Pressure } \\
\text { groups }\end{array}$ & $\begin{array}{l}\text { No tobacco industry } \\
\text { interference in politics. }\end{array}$ & $\begin{array}{l}\text { Complaints against the } \\
\text { tobacco industry }\end{array}$ \\
\hline
\end{tabular}

[1] The WHO definition is not identical to the one accepted in the new ECOWAS directive.

\section{Status Of Tobacco Control Policies In The Ecowas Region}

In general, there is heterogeneity in tobacco control practices across the economic space. These disparities are mainly due to the specific characteristics of each country, such as its size, its type of political system, the degree of interference of tobacco lobbies in its political decisions and its socio-economic development. Indeed, in such countries, the corruption of the political system means that tobacco control advocates are often confronted with the harsh reality of implementing and enforcing laws, as some members of the executive branch (ministers, senior officials, ministerial cabinets, etc.) who must direct or draft these laws may be closely linked to the tobacco industry. As far as community legislation is concerned - sub regional legislation determined in community bodies - it is a hybrid. In principle, it applies equally to all member countries and national legislation is the responsibility of national governments.

However, national legislation ratifies EU laws and establishes other provisions according to the specific needs and objectives of the countries. Moreover, these laws vary considerably: some countries have already adopted a comprehensive national tobacco control law (Burkina Faso, Nigeria); others are in the process of enacting new laws or improving existing laws (Côte d'Ivoire, Mali, Ghana, Senegal) or are beginning to 
develop new policies (Benin, Cape Verde, Gambia, Guinea, Liberia, Niger, Togo, Sierra Leone). Table 2 below presents the economic and social disparities of ECOWAS countries.

Table 2: Economic and Social Disparities in ECOWAS Countries

\begin{tabular}{|c|c|c|c|c|c|c|c|}
\hline $\begin{array}{l}\text { Prevalence of smoking } \\
\text { among persons aged } \\
15 \text { years and older (\%) }\end{array}$ & $\begin{array}{l}\text { Population in } \\
\text { millions of } \\
\text { residents in } \\
2018\end{array}$ & $\begin{array}{l}\text { Number of } \\
\text { tobacco } \\
\text { deaths per } \\
\text { year in } 2018\end{array}$ & $\begin{array}{l}\text { Overall social } \\
\text { cost in millions } \\
\text { of PPP in } 2018\end{array}$ & $\begin{array}{l}\text { Nominal GDP } \\
\text { in billions of } \\
\text { US dollars } \\
2018\end{array}$ & $\begin{array}{l}\text { GDP per } \\
\text { capita in } \\
\text { US dollars } \\
2018\end{array}$ & $\begin{array}{l}\text { Current health } \\
\text { expenditure } \\
\text { as } \% \text { of GDP }\end{array}$ & \\
\hline Benin & 8,3 & 11,5 & 2900 & 17 & 10,36 & 902 & 3,7 \\
\hline Burkina Faso & 19,7 & 19,75 & 4800 & 59 & 14,44 & 731 & 6,9 \\
\hline Cape Verde & 17,6 & 0,543767 & 208 & 3 & 1,99 & 3654 & 5,2 \\
\hline Ivory Coast & 20,3 & 25 & 9000 & 261 & 43,01 & 1716 & 4,5 \\
\hline Gambia & 25,4 & 2,3 & 500 & 5 & 1,62 & 712 & 3,3 \\
\hline Ghana & 5,4 & 29,6 & 5000 & 123 & 65,56 & 2202 & 3,3 \\
\hline Guinea & 6,9 & 12,4 & 4400 & 58 & 10,99 & 885 & 4,1 \\
\hline Guinea-Bissau & 11,4 & 1,8 & 900 & 4 & 1,46 & 718 & 7,2 \\
\hline Liberia & 13,6 & 4,8 & 1042 & 8 & 3,25 & 674 & 8,2 \\
\hline Mali & 18,1 & 19,1 & 2600 & 30 & 17,2 & 901 & 3,8 \\
\hline Niger & 12,4 & 22,5 & 3300 & 2000 & 9,24 & 412 & 7,7 \\
\hline Nigeria & 7,2 & 195,9 & 16100 & 2000 & 397,27 & 2028 & 3,8 \\
\hline Senegal & 12,7 & 15,9 & 4100 & 23 & 24,13 & 1522 & 4,1 \\
\hline Sierra Leone & 29,7 & 7,65 & 3100 & 50 & 4 & 523 & 13,4 \\
\hline Togo & 10,4 & 7,4 & 2300 & 11 & 5,30 & 672 & \\
\hline
\end{tabular}

Sources: tobacco atlas, 2018. WHO World Tobacco Report. Epidemic, 2019. World Bank population totals, 2018. Goodchild, Nargis, and Espaignet, 2018.

Overall, much of what needs to be done in tobacco control in ECOWAS has a direct political component. Even activities that might seem remote from this area, such as information and awareness campaigns about the dangers of tobacco use, can be political in nature if a government institution is involved. This implies that public health policies are essentially local in nature, but it does not negate the importance of international fora for public health, including tobacco control.

\section{Structure Of Excise Duties In Ecowas Countries}

\section{There are several types of tobacco products that are taxable on the regional market. Table 3 below presents the tariff and statistical nomenclature of tobacco products subject to taxation in the ECOWAS region.}

Table 3: Nomenclature and tobacco products 


\begin{tabular}{|ll|}
\hline $\begin{array}{l}\text { Tariff and statistical nomenclature } \\
\text { (HS 2017) }\end{array}$ & Products \\
\hline 2402.10 .00 .00 & Cigars and cigarillos containing tobacco \\
\hline 2402.20 .00 .00 & Cigarettes containing tobacco \\
\hline 2402.90 .00 .00 & Cigars, cigarillos and tobacco substitutes \\
\hline 2403.11 .00 .00 & Water pipe tobacco \\
\hline 2403.19 .00 .00 & Other smoking tobacco containing tobacco substitutes in any proportion \\
\hline 2403.91 .00 .00 & Homogenized or reconstituted tobacco \\
\hline 2403.99 .10 .00 & \begin{tabular}{l} 
Expanded tobacco husks \\
Chewing tobacco, snuff, press or sauce tobacco, tobacco extracts and sauces, manufactured \\
\hline 2403.99 .90 .00
\end{tabular} \\
\hline
\end{tabular}

Source: new ECOWAS directive C/DIR.1/12/17

The tobacco products described in this table are necessarily subject to mixed taxation: an ad valorem duty and a specific duty. In practice, this combination of taxes is rarely deployed in the Economic Union, probably due to a lack of political will or the weakness of tax administrations.

The tax base for the ad valorem duty is composed of:

- on import, by the customs value plus the duties and taxes levied on entry, excluding value added tax (VAT) and excise duties.

- for locally manufactured products, by the ex-factory selling price or the cost of production, excluding VAT and excise duties.

The taxable amount of the specific duty is composed of:

- per rod, for cigarettes, cigars and cigarillos.

- by weight expressed in kilograms, for all other tobacco products.

Table 4 below presents details of taxes on the most popular brand in the various countries of the economic zone. It provides an analysis of the main tax instruments used and their operating mechanisms in order to better understand the taxation of tobacco products in the subregion.

Table 4: Taxes on top selling brand (\% of retail price) in 2017 (before the new directive) 


\begin{tabular}{|c|c|c|c|c|c|c|c|}
\hline Country & $\begin{array}{l}\text { Price of a pack of } 20 \\
\text { cigarettes }\end{array}$ & $\begin{array}{l}\text { Local } \\
\text { currency }\end{array}$ & $\begin{array}{l}\text { special } \\
\text { rate }\end{array}$ & $\begin{array}{l}\text { Ad valorem } \\
\text { rate }\end{array}$ & VAT & $\begin{array}{l}\text { Customs } \\
\text { duties }\end{array}$ & $\begin{array}{l}\text { Other } \\
\text { taxes }\end{array}$ \\
\hline Benin & 500 & XOF & & $40 \%$ & $1,40 \%$ & & $0,37 \%$ \\
\hline Burkina Faso & 750 & XOF & & $30 \%$ & $15,25 \%$ & & \\
\hline Cape Verde & 180 & CVE & & $10 \%$ & $3,35 \%$ & $5,18 \%$ & $0,07 \%$ \\
\hline Ivory Coast & 700 & XOF & & $35 \%$ & $15,25 \%$ & & $2,14 \%$ \\
\hline Gambia & 60 & GMD & $33,33 \%$ & $30 \%$ & $6,57 \%$ & $1,74 \%$ & $4,67 \%$ \\
\hline Ghana & 4,99 & GHS & & $150 \%$ & $14,89 \%$ & & $0,34 \%$ \\
\hline Guinea & 3500 & GNF & & $15 \%$ & $6,35 \%$ & $5,17 \%$ & $0,71 \%$ \\
\hline $\begin{array}{l}\text { Guinea- } \\
\text { Bissau }\end{array}$ & 500 & XOF & & $25 \%$ & $1,92 \%$ & $1,27 \%$ & $0,15 \%$ \\
\hline Liberia & 120 & LRD & & $35 \%$ & $9,09 \%$ & $1,43 \%$ & $0,14 \%$ \\
\hline Mali & 800 & XOF & & $25 \%$ & $9,19 \%$ & $6,51 \%$ & $0,81 \%$ \\
\hline Niger & 500 & XOF & & $40 \%$ & $15,97 \%$ & & $0,86 \%$ \\
\hline Nigeria & 220 & NGN & $9,09 \%$ & $20 \%$ & $4,76 \%$ & & \\
\hline Senegal & 700 & XOF & & $45 \%$ & $15,25 \%$ & & \\
\hline Sierra Leone & 5000 & SLL & & $0 \%$ & $13,04 \%$ & & $0,08 \%$ \\
\hline Togo & 600 & XOF & & $40 \%$ & $15,25 \%$ & & $0,53 \%$ \\
\hline
\end{tabular}

Source: WHO, 2019

At the global level, taxation policies for the best-selling brand of tobacco products can be classified into two distinct groups: a group in which countries apply no significant taxation, namely Cape Verde, Guinea, Guinea Bissau, Nigeria and Sierra Leone, and another majority group in which taxes are very low, namely Burkina Faso, Côte d'Ivoire, Gambia, Mali, Niger, Senegal and Togo. Ghana has the highest tax rate in the economic zone, probably to show a real political will to fight against tobacco use. From these lessons, the countries adopt different tax policies but the challenges they face are relatively the same. In the short to medium term, they will need to examine the relationship between market structures and taxation to determine an optimal tax regime. The effectiveness of a tax system depends on a few factors, including the extent to which firms pass on increased taxes to their customers. This pass-through depends on the structure of the taxes but also on the configuration of the market, which may or may not give market power to incumbent firms [7]. This pass-through depends on the structure of the taxes but also on the configuration of the market, which may or may not give market power to incumbent firms [7]. The sub regional market is characterized by oligopolistic competition, while domestic markets are dominated by a private quasi-monopoly, except in Cape Verde where it is public[1].

Most international firms produce mainly high-end cigarettes, while local manufacturers are more focused on the production of economy cigarettes. Although these two categories are relatively homogeneous in terms of quality, the selling prices offered are different. This distinction can tell us something about the political will to tax, for which the economist's role is to propose regulatory tools to the legislator. Thus, the legislator's normative interventions may aim to increase tax revenues. Since tax levels differ between countries in the economic zone, the need to harmonize them leads to the question of the type of tax to be applied according to the structure of the market. While in perfect competition, the two taxes generally lead to an identical result in terms of price, profit and tax revenue [8], insofar as they directly and fully affect the selling price [9], this is not the case in imperfect competition. Indeed, if the public authorities want to carry out a public health action, it seems more coherent to apply a tax on the quantity and not on the price of cigarettes, because a specific tax would only affect usage, whereas an ad valorem tax would only increase the price [10]. Regardless of the type of tax considered, to discourage smokers from switching to cheaper brands if the most consumed brand increases, a minimum collection price and/or a merger of tax levels can be imposed to try to achieve this objective. European countries, in their tobacco control efforts, apply a combination of taxes combined with a minimum tax, whereas for ECOWAS countries, even though the various EU directives recommend combining the two taxes, this combination is not widely deployed: among these 15 countries, Cape Verde, Gambia, Guinea-Bissau and Nigeria are the only ones to apply a specific tax in addition to the ad-valorem tax, and Senegal is the first country, at present, to have recently imposed [2]this minimum tax. The usefulness of this mixed strategy combined with a minimum tax is that it equalizes the price increase across all brands, forcing smokers to quit rather than switch to another brand. It is also intended to discourage cross-border purchases between neighboring countries. As things stand, within ECOWAS, while it is recognized that it is difficult to predict the impact, both in prevalence and intensity, of a price increase on consumption, while taking into 
account the willingness to pay of drug users and/or the poor because they are less inclined to give up consumption, it appears necessary for policy makers to look upstream at the links between taxation, public health, and excise revenues.

The link between tobacco taxation, public health and excise revenues is not just theoretical. Indeed, several recent empirical studies, cited in the WHO Technical Manual on Tobacco Tax Administration [3]or in the World Bank Group Consultants' Toolkit on the Economics of Tobacco[4] Taxation, point out that in all countries of the world, low-income smokers are more sensitive to price changes and are therefore more likely to quit smoking [11]. In this sense, econometric studies clearly show that increasing tobacco prices through taxation leads to a reduction in overall tobacco consumption, smoking prevalence and frequency of use. Moreover, the effect is particularly strong among young people and people with low incomes [12]. The elasticity of demand is estimated to be between $\mathbf{- 0 . 2}$ and $\mathbf{- 0 . 6}$ and concentrated around $\mathbf{- 0 . 4}$ for high-income countries, while it is between $\mathbf{- 0 . 2}$ and $\mathbf{- 0 . 8}$ and concentrated around $\mathbf{- 0 . 5}$ for low-income countries [12]. A 10\% increase in cigarette prices is expected to reduce demand by $4 \%$ for high-income countries and $5 \%$ for low-income countries [12].

All else being equal, the more inelastic the demand, the greater the tax revenue surplus, regardless of the excise regime applied [11]. Finally, it seems that tobacco price increases resulting from higher taxes have more beneficial effects on the health of low-income people. This relationship is poorly documented for ECOWAS countries. A study conducted by the Consortium for Economic and Social Research (CRES) points out that The Gambia, which applies a specific duty (rarely applied by EU countries), recovers more than $60 \%$ of tobacco excise revenues [7]. The ongoing study for Ghana may shed more light on this link, as the country adopts an aggressive tax strategy precisely to increase government tax revenues.

[1] The Cape Verdean government has exclusive import contracts.

[2] http://www.droit-afrique.com/uploads/Senegal-LF-2018-rectificative.pdf)

[3]https://apps.who.int/iris/bitstream/handle/10665/44316/9789241563994_eng.pdf;jsessionid=378B273D8B27FD09A6FD7DD51D99B1D7? sequence $=1$

[4]http://documents.worldbank.org/curated/en/926851541190614820/pdf/Economics-of-Tobacco-Taxation-Toolkit.pdf

\section{Assessment Of The Level Of Implementation Of The New Directive}

The assessment of the application of the new directive in the countries of the Economic Union will be made based on excise duties or equivalents, customs duties, VAT or equivalents or other special taxes, respectively.

\section{Excise duties}

Excise taxes (specific taxes and ad valorem rates) on products are the main way to increase the price of tobacco compared to other taxes. Thus, two groups of countries can be classified according to the implementation of the new directive: a majority group composed of (Burkina Faso, Cape Verde, Côte d'Ivoire, Gambia, Guinea, Guinea-Bissau, Liberia, Mali, Nigeria, Niger and Sierra Leone) that had not reached the tax ceiling of the previous directive.

In these countries, although efforts to increase taxation have been observed, only Burkina Faso, Cape Verde, and Liberia have managed to reach the tax base (50\%) recommended in the new directive, while the others continue to apply a lower excise duty. A minority group (Benin, Senegal, and Togo) were at the tax ceiling of the previous directive. These countries have made relatively greater efforts in taxation than the minority group, as they have exceeded the basic excise duty. Specifically, Togo increased its minimum rate by a factor of three, Benin by a factor of two, and Senegal by about one and a half. Ghana's taxation is a special case. It is the only country that had far exceeded the tax ceiling of the previous directive. Unsurprisingly, it continues to do so by further increasing its level of taxation, which clearly responds to a logic of increasing government tax revenues and, to a lesser extent, protecting local manufacturers.

\section{Customs duties}

Customs duties are also called import duties. They are taxes applied by a country on all products entering its territory. Customs taxes ranging from 5 to $45 \%$ are part of the ECOWAS Common External Tariff (CET) and are supposed to be identical. Increasing them is a way to raise the price of imported tobacco products but also to exercise a form of protectionism for local industries. This may explain the high taxation of tobacco products in Ghana. However, because of trade agreements between countries and even within an economic union, it is difficult to rely solely on higher tariffs to achieve the public health and economic goals of tobacco control. Overall, even if tariffs are regulated at the EU level, they are relatively too low, which hurts government tax revenues. 


\section{VAT or equivalent}

Value added tax (VAT) is levied on all goods and services circulating in the ECOWAS region. The Union has determined a range of 5 to 20 percent for the VAT, but its actual value is left to member states. In recent years, some countries have tried to use VAT to increase the price of certain goods and services, but the increase does not create a significant price differential between tobacco products and other goods and services. Moreover, the large difference between VAT levels does not facilitate a pricing policy based solely on this lever.

\section{Other taxes or special taxes}

Tobacco products may be subject to other taxes (surcharges) levied only on tobacco or on other specific consumer products. In fact, these surcharges, which are the responsibility of national governments (they are not regulated at the EU level), vary considerably across ECOWAS countries and are levied to correct a negative externality caused by the consumption of certain products such as tobacco. In contrast, the statistical levy, the national solidarity levy and the community levy are surcharges imposed by ECOWAS on all member states.

\section{The details of this information are presented in Table 5 below.}

Table 5: Tax structure of the most sold tobacco products in ECOWAS countries in 2020 


\begin{tabular}{|c|c|c|c|c|c|}
\hline Country & specific tax & Ad valorem tax & VAT & Customs duties & Other taxes \\
\hline Benin & & $100 \%$ & $18 \%$ & {$[5-20 \%]$} & Ecotaxes 5 \\
\hline Burkina Faso & & $50 \%$ & $18 \%$ & [5-20\%] & NR \\
\hline Cape Verde & 20CVE/stem/cig & $50 \%$ & $15 \%$ & {$[20-50 \%]$} & Ecotaxes on cigarettes and cigarillos $5 \%$. \\
\hline \multirow[t]{2}{*}{ Ivory Coast } & & \multirow[t]{2}{*}{$45 \%$} & \multirow[t]{2}{*}{$21 \%$} & \multirow[t]{2}{*}{ [5-20\%] } & Special tax for the dev. Sport [ $2.5-10 \%]$ \\
\hline & & & & & Solidarity and AIDS tax $2 \%$. \\
\hline \multirow[t]{2}{*}{ Gambia } & \multirow[t]{2}{*}{$33,33 \%$} & $25 \mathrm{D} /$ pack $20 \mathrm{cig}$ & \multirow[t]{2}{*}{$15 \%$} & \multirow[t]{2}{*}{$20 \%$} & Environmental tax $2.93 \mathrm{D} /$ pack of cigarettes \\
\hline & & 363D/kg Other cig & & & Environmental tax $175 \mathrm{D} / \mathrm{kg} /$ other cigarettes \\
\hline \multirow[t]{5}{*}{ Ghana } & & \multirow[t]{5}{*}{$175 \%$} & \multirow[t]{5}{*}{$13 \%$} & \multirow[t]{5}{*}{$20 \%$} & National health tax $2.5 \%$. \\
\hline & & & & & GETFL levy $2.5 \%$ \\
\hline & & & & & FIDE levy $0.5 \%$ \\
\hline & & & & & Customs transaction fees $3.5 \%$. \\
\hline & & & & & Export Development Tax $1 \%$ \\
\hline \multirow[t]{2}{*}{ Guinea } & & \multirow[t]{2}{*}{$30 \%$} & \multirow[t]{2}{*}{$18 \%$} & \multirow[t]{2}{*}{ [5-20\%] } & Withholding on liquidation securities $2 \%$. \\
\hline & & & & & Additional cents $0.25 \%$. \\
\hline Guinea-Bissau & 10FCFA/stem/cig & $45 \%$ & $15 \%$ & [5-20\%] & Personnel costs $1.52 \%$. \\
\hline Liberia & & $50 \%$ & $7 \%$ & $5 \%$ & NR \\
\hline \multirow[t]{2}{*}{ Mali } & & \multirow[t]{2}{*}{$32 \%$} & \multirow[t]{2}{*}{$18 \%$} & \multirow[t]{2}{*}{ [5-20\%] } & $5 \%$ degressive protection tax. \\
\hline & & & & & Anti-smoking and solidarity tax $5 \%$. \\
\hline \multirow[t]{3}{*}{ Niger } & & \multirow[t]{3}{*}{$50 \%$} & \multirow[t]{3}{*}{$19 \%$} & \multirow[t]{3}{*}{ [5-45\%] } & Flat tax on public transport: 0.25 \\
\hline & & & & & Special re-export tax of $5 \%$. \\
\hline & & & & & Import verification tax: $1 \%$ \\
\hline Nigeria & 1NGN/stem/cig & $20 \%$ & $7.5 \%$ & [5-35\%] & Surtax on imports of certain products [50-100\%]. \\
\hline \multirow[t]{2}{*}{ Senegal } & & \multirow[t]{2}{*}{$65 \%$} & \multirow[t]{2}{*}{$18 \%$} & \multirow[t]{2}{*}{ [5-20\%] } & Surtax on imported cigarettes $20 \%$. \\
\hline & & & & & Tax on imports by sea $0.2 \%$. \\
\hline Sierra Leone & & $35 \%$ & $15 \%$ & $10 \%$ & NR \\
\hline \multirow[t]{3}{*}{ Togo } & & \multirow[t]{3}{*}{$150 \%$} & \multirow[t]{3}{*}{$18 \%$} & \multirow[t]{3}{*}[5-20\%]{} & Statistical fees $1 \%$. \\
\hline & & & & & $1 \%$ national solidarity levy. \\
\hline & & & & & Community solidarity levy $1 \%$. \\
\hline
\end{tabular}

Overall, all member states have made relatively strong efforts to increase basic excise taxes in the hopes of reducing smoking prevalence and increasing tax revenues in the long run.

They will still need to think about an optimal tax system that would increase tax revenues in the long run, as this is the key issue in convincing policymakers to implement tax reforms.

The following chart shows excise duty data for ECOWAS countries in 2018.

\section{Conclusion}

States should focus on actions to reduce not only trafficking but also demand, for reasons of responsibility on the one hand, and on the other hand, to put in place effective and coherent prevention strategies. Although developments have recently been observed in Africa, particularly in ECOWAS countries, with smoking bans in public places or advertising restrictions, many efforts remain to be made, such as comprehensive prevention policies. 
The main objective of this research is to evaluate the implementation of the new ECOWAS directive on tobacco taxation. It shows that most countries in the Economic Union should increase their efforts in the area of tobacco taxation by trying to continuously increase excise duties. This could help reduce demand and thus limit the health and economic damage caused by tobacco use. In addition, this strategy would provide governments with additional resources to promote health education for all.

Based on these lessons, we finally suggest that tax authorities in ECOWAS countries continuously increase tax levels in line with inflation and changes in disposable income per capita to make tobacco products more difficult to purchase. This is especially true since low-income people are more sensitive to any price increase. In addition, most EU countries rely on a tax system based solely on an ad valorem rate, which makes it difficult to achieve public health and economic objectives. Therefore, countries should evolve this regime with a specific tax as suggested in the new directive, knowing that this mixed strategy is more flexible in administration and more efficient in the long run. In addition, most member states set different levels of taxation between imported and locally produced tobacco products, and between high-end and low- or mid-range cigarettes. It would be appropriate to reflect on a more coherent level of taxation that would not allow for a shift from one product to another or from one range to another. At the same time, these technical considerations must be combined with a real political will at both community and national levels. Thus, even though ECOWAS has set up a monitoring committee composed of the main actors in tobacco control, whose role is to draw up a bi-monthly evaluation report, it is marked by a certain laxity because this work has not yet been carried out, yet it is useful to know the common or specific constraints linked to the application of the new directive in order to be able to make the necessary arbitrations. We therefore recommend that this evaluation report be carried out, which would allow for a better assessment of the effectiveness of the provisions of such a directive in terms of tax revenues. At the national level, political efforts in tobacco control should also be reflected in the long-term actions undertaken by governments. To improve the coherence of strategies, we recommend that governments include them in a multi-year health program with specific targets.

\section{References}

1. WHO report on the global tobacco epidemic, 2019. Geneva: World Health Organization;2019. License: CC BY-NC-SA 3.0 IGO. https://apps.who.int/iris/bitstream/handle/10665/326043/9789241516204-eng.pdf?ua=1.

2. Verez JC. Economic, demographic and migration issues European Union-Africa. Europe in formation.2019;(388):9-26.

3. United Nations, department of economic and social affairs, population division (2017). World population prospects. United Nations.

4. Gallien M. Decoupling tobacco taxes from illicit trade in Africa. International Center for Tax and Development (ICTD).2019. Policy Brief No. 22. https://opendocs.ids.ac.uk/opendocs/bitstream/handle/20.500.12413/15325/ICTD_SumBrief\%2022_FRENCH_2.0.fr.pdf? sequence=9\&isAllowed $=\mathrm{y}$.

5. World Health Organization (WHO). Who accounts for the global tobacco epidemic, 2015: raising tobacco taxes? World Health Organization.2015. https://www.afro.who.int/sites/default/files/2017-06/ng.pdf.

6. World Health Organization (WHO). Earmarked tobacco taxes: lessons learned from nine countries.2016. World Health Organization (WHO). https://apps.who.int/iris/bitstream/handle/10665/252185/9789242510424-fre.pdf?sequence=1.

7. Diagne A et al. Evaluation of the economic cost of tobacco-related diseases in Senegal. Consortium for Economic and Social Research (CRES).2017. http://www.cres-tabac.com/notes/FactSheet_Cout_tabagisme_Global.pdf

8. Boldron F. The choice between unitary and ad valorem taxes. Revue française d'économie.2003;17(3):109-128. doi: https://doi.org/10.3406/rfeco.2003.1468.

9. Skeath SE, Trandel GA. A pareto comparison of ad valorem and unit taxes in noncompetitive environments. Journal of public economics.1994;53(1):53-71. https://www.sciencedirect.com/science/article/abs/pii/0047272794900132?via\%3Dihub.

10. Keen M. The balance between specific and ad valorem taxation. Fiscal studies.1998;19(1):1-37.

11. Marquez PV, Moreno-Dodson B. Tobacco tax reform at the crossroads of health and development: A multisectoral perspective. World Bank Group (2017). https://openknowledge.worldbank.org/bitstream/handle/10986/28494/119792-REVISED-v2-FINAL-WBGTobaccoTaxReform-FullReport-web.pdf? sequence=1\&isAllowed=y.

12. S. National Cancer Institute and World Health Organization (2016). The economics of tobacco and tobacco control. National Cancer Institute Tobacco Control Monographs 21. NIH Publication No. 16-CA-8029A. https://cancercontrol.cancer.gov/brp/tcrb/monographs/21/docs/m21_complete.pdf 